Dangiras Mačiulis

Lietuvos istorijos institutas dangirasmaciulis@yahoo.com

ORCiD: 0000-0001-6496-1538

\title{
Jak kino białoruskie w okresie sowieckim opowiadało historię II wojny światowej
}

Obraz drugiej wojny światowej był mocno podkreślany w sowieckiej białoruskiej kulturze pamięci, co wynikało nie tylko z polityki historycznej państwa sowieckiego. Wojna naprawdę pozostawiła głęboki ślad w białoruskiej pamięci zbiorowej. W białoruskim studiu filmowym Belarusfilm (Беларусьфільм) powstało około 70 filmów fabularnych, których tematem była historia II wojny światowej. W niniejszym artykule analizuje się sposób, w jaki wytwórnia filmowa Belarusfilm w latach 1946-1985 tworzyła filmy opowiadające historię II wojny światowej. Autor podjął próbę znalezienie odpowiedzi na pytanie, w jaki sposób filmy fabularne o wojnie odzwierciedlały obowiązującą w ZSRS wykładnię historii wojny. Autor analizuje filmy fabularne o II wojnie światowej, które urosły do rangi kanonu sztuki filmowej. W ZSRS o wojnie otwarcie zaczęto mówić dopiero w czasach odwilży Chruszczowa (1953-1964). Zaczęto szeroko wykorzystywać zwycięstwo nad nazizmem zarówno do legitymizacji reżimu politycznego, jak i do konstruowania sowieckiej tożsamości. W studiu Belarusfilm kręcono filmy na temat wojny, których treść odzwierciedlała główne nurty sowieckiej narracji o wojnie. Szczególną uwagę poświęcono sowieckim partyzantom walczącym z okupantem.

Słowa kluczowe: Il wojna światowa, okres sowiecki, Białoruś, kino

Historyk kina Neja Zorkaja zauważyła, że „śledząc ewolucję filmu wojennego, można poznawać powojenną historię Związku Radzieckiego, następstwo okresów historycznych, paternalizację władzy i tajny 
sprzeciw artystów"1. W okresie sowieckim w białoruskim studiu filmowym Belarusfilm («Беларусьфільм») przygotowano około siedemdziesięciu filmów fabularnych, opowiadających historię II wojny światowej oraz wykorzystujących jej wspomnienia. Filmy o tematyce wojennej stanowiły tak dużą część produkcji filmowej studia, że zaczęto je nazywać studiem filmowym Partizanfilm. Bogata spuścizna kinematograficzna daje możliwość na podstawie filmów, powstałych w studiu, uważniej przyjrzeć się reprezentacji pamięci o wojnie w białoruskim filmie sowieckim - uwydatnić zarówno dominującą tematykę i wątki, jak i dynamikę oficjalnego ukazywania wojny. Mając na uwadze bogatą reprezentację filmową dotyczącą wojny, w artykule zamierzamy jedynie podzielić się uwagami na temat, jak w powstałych w studiu Belarusfilm w latach 1946-1985 filmach fabularnych opowiedziano historię II wojny światowej. Spróbujemy odpowiedzieć na pytania: czy filmowa opowieść o wojnie była odbiciem oficjalnej polityki historycznej systemu sowieckiego i jak wyglądała dynamika opowiadania o tym wydarzeniu. Jednocześnie spróbujemy pokazać cechy białoruskiej narracji filmowej dotyczącej wojny.

W pierwszych latach powojennych reżim polityczny Związku Radzieckiego pamięć o wojnie, której symbolem stał się Dzień Zwycięstwa, aktywnie wykorzystywał do legitymacji swojej władzy i mobilizacji społeczeństwa. Zaraz po tym, jak Niemcy w 1945 r. podpisały akt bezwarunkowej kapitulacji parlament sowiecki ogłosił 9 maja ogólnoludowym świętem - Dniem Zwycięstwa, wolnym od pracy. Święto uroczyście obchodzono w latach 1946-1947, jednak pod koniec 1947 r. podjęto decyzję o uchyleniu dnia wolnego - Dzień Zwycięstwa stał się zwykłym dniem pracy. Po 1947 r. oficjalna pamięć o wojnie w Związku Radzieckim była dwuznaczna. W dalszym ciągu obchodzono Dzień Zwycięstwa i czczono pokonanie faszyzmu przez Związek Radziecki i jednocześnie próbowano zdewaluować symboliczny kapitał Zwycięstwa. Służyło temu m.in. wspomniane obniżenie statusu święta 9 maja

${ }^{1}$ Н. Зоркая, История отечественного кино. ХХ век, Москва 2014, с. 303. 
oraz fala powojennych represji przeciwko sowieckim generałom, którzy potencjalnie mieli najwięcej roszczeń i ambicji do korzystania z kapitału zwycięstwa ${ }^{2}$. Taka dewaluacja wartości miała na celu nie minimalizację wagi pokonania wroga, lecz stworzenie przesłanek do tego, by symboliczny kapitał zwycięstwa mogła skupić w swoich rękach jedna osoba - Józef Stalin, którego propaganda sowiecka przedstawiała jako głównego architekta światowego pogromu faszyzmu.

Oficjalna pamięć o wojnie w dyskursie propagandowym w latach stalinizmu charakteryzowała się tym, że opowieść o wojnie przekształcono w heroiczną narrację o bohaterskiej i ofiarnej walce ludu sowieckiego z okupantem oraz udanej misji wyzwalania narodów europejskich, podbitych przez nazistów. Milczano o tych wydarzeniach, które, jak uważano, mogły osłabić monolityczny wizerunek heroicznej walki ludu sowieckiego (fakty masowego oddawania się do niewoli żołnierzy sowieckich w pierwszych miesiącach wojny, liczne przypadki kolaboracji z nazistami, błędy sowieckiej generalicji i in.). Opowieści o wojnie używano przy tym do umocnienia kultu Stalina - w zasadzie jedynie on miał prawo do korzystania z symbolicznego kapitału zwycięstwa.

Pierwsze sowieckie filmy fabularne o wojnie powstały podczas jej trwania, gdy wielki ekran w całości służył jako narzędzie propagandy, którego zadaniem było budzenie sowieckiego patriotyzmu, zaszczepianie nienawiści wobec wroga i wiara we własne zwycięstwo ${ }^{3}$. Powojenne filmy poświęcone wojnie utraciły swoją wcześniejszą funkcję mobilizacyjną: odtąd miały służyć legitymowaniu sowieckiego reżimu i umacnianiu kultu Stalina. Jednak w owym czasie filmów o tematyce wojennej powstało stosunkowo niewiele, tak jak w całym kraju powstawało wtedy niewiele filmów fabularnych ${ }^{4}$. Za wzorzec stalinowskiej opowieści o wojnie można uznać dwuczęściowy obraz w reżyserii Michaiła Cziaureli

${ }^{2}$ Д. Андреев, Г. Бордюгов, Пространство памяти: Великая Победа и власть, Москва 2005, с. 9-14.

${ }^{3}$ Н. Зоркая, op. cit., с. 252.

${ }^{4}$ История отечественного кино, ред. Л. М. Будяк, Москва 2005, с. 342. 
z 1949 r. Upadek Berlina («Падение Берлина»), w którym widz poznawał heroiczną opowieść o bohaterskiej walce ludu sowieckiego z okupantem oraz wizerunek Stalina jako zwycięskiego dowódcy wojskowego.

W kulturze pamięci sowieckiej Białorusi wojna zostawiła jednak głęboki ślad. Z jednej strony oznaczała straty i ofiary, z drugiej - wystąpiło zjawisko masowego sprzeciwu wobec okupanta, gdyż w 1944 r., w przeddzień wyzwolenia Białorusi, na terenie kraju działało około 370 tys. partyzantów ${ }^{5}$. Mając na uwadze owo doświadczenie społeczne, sowieccy ideolodzy ruszyli machinę propagandową, a to z kolei doprowadziło do stworzenia białoruskiego mitu republiki partyzantów, który wpajano, stosując najprzeróżniejsze sposoby - poczynając od uwiecznienia pamięci o poległych, kończąc na masowym wydawaniu wspomnień partyzantów ${ }^{6}$. Jak twierdzi białoruski filozof Valiancin Akudovič, tak zrodził się „pierwszy ogólnonarodowy białoruski mit”7 - Białorusi jako kraju partyzantów.

Jesienią 1949 r. na ekranach kin Związku Radzieckiego pokazano pierwszy film wyprodukowany przez Belarusfilm, opowiadający o wojnie. Było to dzieło reżyserów Uladzimira Korš-Sablina i Aleksandra Fajncymmera Konstantin Zasłonow («Константин Заслонов»), które prezentowano jako opowieść o „wiernym synu narodu białoruskiego, chlubnym przywódcy partyzantów w Orszy, bohaterze Związku Radzieckiego Konstantinie Zasłonowie". Film ten stanowił początek opowieści kinowej o białoruskich sowieckich partyzantach. Jest tu też pierwsza filmowa kreacja Wilhelma Kube, gauleitera Okręgu Generalnego Białoruś - uosabiająca w ówczesnym kinie sowieckim obraz okrutnego, bezlitosnego nazisty ${ }^{8}$.

53. Шыбека, Нарыс гісторыі Беларусі. 1795-2002, Мінск 2003, с. 325, 331, 336.

${ }^{6}$ Р. Лінднэр, Гісторыкі і уллада: нацыятворчы працэс і гістарычная палітыка у Беларусі XIX-XX cm., Санкт-Петербург 2005, с. 349-358.

${ }^{7}$ В. Акудовіч, Код адсутнасиі (асновы беларускай ментальнасиі), Мінск 2007 , с. $60-71$.

${ }^{8}$ А. Орлова, Способы воплощения «образа врага» в советском киноискусстве 1940-х годов (на материале художественных фульмов о Великой Отечествен- 
Krytycy oficjalnie ocenili ten film jako w zasadzie prawdziwie ukazujący „walkę śmiałych sowieckich patriotów - białoruskich partyzantów przeciwko niemieckim faszystom". Pojawily się jedynie delikatne uwagi, że autorzy filmu mogli petniej i szerzej pokazać ogólnoludowy charakter ruchu partyzanckiego na Białorusi i mocniej uwydatnić narodowy koloryt białoruski ${ }^{9}$. O przychylności zideologizowanej krytyki zadecydował fakt, iż, jak wówczas twierdzono, poprawnie ukazano anatomię heroizmu: bohater działał pod kierownictwem podziemnej partyjnej organizacji komunistycznej ${ }^{10}$. Oficjalna sowiecka narracja dotycząca historii wojny podkreślała wiodącą rolę partii komunistycznej, co nasuwało myśl, że wszystkie działania wojenne były prowadzone za wiedzą partii. Przypomnijmy, że wcześniejszy film w reżyserii Siergieja Gierasimowa Młoda gwardia («Молодая гвардия») skrytykowano za to, że w niedostatecznym stopniu podkreślono w nim rolę partii, kierującej antyfaszystowskim podziemnym ruchem oporu ${ }^{11}$.

Filmowy obraz Zasłonowa pokazywał nowego bohatera sowieckiej Białorusi. W 1949 r. w kronice filmowej Sowiecka Białoruś («Савецкая Беларусь» 1949, №25) opowiedziano historię o tym, jak w kołchozie Czerwony Oracz pokazano film Konstantin Zastonow, a seansowi filmowemu towarzyszyła opowieść kinomechanika „o ofiarnej walce partyzantów białoruskich oraz legendarnym synu narodu białoruskiego Konstantinie Zasłonowie". Był to jedyny film o wojnie przygotowany w powojennych latach stalinowskich przez białoruskich twórców kina, jednak jak już wspomniano, w tym czasie w Związku Radzieckim w ogóle powstawało mało filmów.

ной войне), «Вестник Костромского государственного университета им. Н. А. Некрасова» 2015, № 4, с. 30 .

${ }^{9}$ В. Ливенцов, Патриотический фильм, «Известия» 1949, 13 сентября.

${ }^{10}$ А. Земцов, Фильм о патриотическом подвиге, «Правда» 1949, 12 сентября.

${ }^{11}$ А. Воронов, Проблема правдоподобия и правды в советских и российских художественных фильмах, посвященных Великой Отечественной войне, «Вестник Ленинградского государственного университета им. А. С. Пушкина» 2010, № 2 , c. 225 . 
Po śmierci Stalina w 1953 r. w ZSRR nastąpił okres odwilży politycznej, a kolejny przywódca Nikita Chruszczow zainicjował rewizję oficjalnej pamięci dotyczącej wojny, uwarunkowaną realizacją polityki destalinizacji. Nowy lider Związku Radzieckiego potrzebował takiej opowieści o wojnie, która przede wszystkim pozbawiłaby możliwości wiązania imienia Stalina ze zwycięstwem. Pamięć o wojnie próbowano umieścić w krajobrazie militarystycznym - przede wszystkim jako własność weteranów i żołnierzy ${ }^{12}$.

W okresie odwilży kontynuowano ukształtowaną w latach stalinizmu, sowiecką opowieści o wojnie, stanowiącą potwierdzenie pokojowego nastawienia ZSRR, jedności moralno-politycznej ludu sowieckiego, który uratował Europę od faszyzmu, oraz heroizmu tegoż ludu. W narracji tej nie przetrwał tylko wątek o wiodącej roli Stalina jako architekta sowieckiego zwycięstwa. Jego miejsce zajęła znacznie silniej akcentowana rola partii komunistycznej. Bardziej otwarcie przemówiono o stratach i ofiarach - opowiadanie o traumatycznym doświadczeniu rozumiano jako świadectwo ,prawdy o wojnie“"13. Wraz z filmami Leca żurawie («Летят журавли», 1957, reż. Michaił Kałatozov), Ballada o żotnierzu («Баллада о солдате», 1959, reż. Grigorij Czuchraj) czy Los człowieka («Судьба человека», 1959, reż. Siergiej Bondarczuk) w sowieckiej opowieści filmowej o wojnie pojawił się nowy typ bohatera i sposoby jego prezentacji. Bohater nie był człowiekiem idealnym, a jego wyczyn nie stanowił wykonania „odgórnego" rozkazu, ale był świadomym samodzielnym wyborem ${ }^{14}$. Reżyserzy skupili uwagę na wojennych losach zwykłego człowieka, jego traumatycznych doświadczeniach, co dało okazję do rewizji oficjalnej uproszczonej opowieści o wojnie. Ze swojej strony oficjalna krytyka okresu odwilży często zarzucała twórcom, że rzekomo skupiają uwagę

${ }^{12}$ Д. Андреев, Г. А. Бордюгов, op. cit., с. 15-18.

${ }^{13}$ Н. Копосов, Память строгого режима. История и политика в России, Москва 2011, с. 100.

${ }^{14}$ Н. Зоркая, ор. cit., s. 303-304; А. Горных, Медиа и общество, Vilnius 2013, c. 91-102, 134. 
na nieistotnych przeżyciach zwykłych ludzi zamiast ukazywać masowy heroizm ludu sowieckiego ${ }^{15}$.

Sowieckie filmy o wojnie zazwyczaj opierały się na prostej czarno-białej opozycji propagandowej ${ }^{16}$, z kolei w latach odwilży narracja filmowa zyskała więcej barw i odcieni. Przykładem nowej opowieści stał się film Droga przez cmentarz («Через кладбище», reż. Viktar Turaŭ), którego premiera odbyła się 5 kwietnia 1965 r. Był to pierwszy białoruski obraz, w którym podjęto próbę obiektywnego ukazania wojny partyzanckiej i codzienności pod okupacją niemiecką oraz zacierającą się granicę między walczącymi stronami: pokazano lokalnych mieszkańców, czekających na sowieckich partyzantów, łączników partyzanckich, którzy nie czują ślepej nienawiści wobec wroga; pojawiła się nawet drwiąca krytyka marszałków Stalina, Klimienta Woroszyłowa i Siemiona Budionnego. W filmie nie ukazano podniosłego heroizmu. Reżyser skupił uwagę na przeżyciach i nastrojach ludzi - ogólnej atmosferze owego czasu. Jednak dzieło to nie stanowiło zamachu na istotę mitu zwycięstwa, a dla ówczesnej cenzury i krytyki, jak zauważono, było ważne nie tyle to, o czym myśleli bohaterowie, lecz że „działali [oni] wyłącznie w odpowiednim kierunku" ${ }^{\prime 1}$. W kinematografii białoruskiej lat sześćdziesiątych od reżysera żądano w prawdzie takiej konstrukcji obrazu, by bohater odzwierciedlał na ekranie tak zwany humanizm socjalistyczny, rzekomo charakterystyczny dla sowieckiego człowieka ${ }^{18}$, przy czym paradoksalnie przekraczano przy tym ideologiczne ramy oficjalnej narracji historycznej, czemu sprzyjała otwarta dyskusja o zachowaniach człowieka w sytuacjach ekstremalnych.

${ }^{15}$ А. Воронов, op. cit., s. 226-227.

${ }^{16}$ А. Федоров, Структурный анализ медиатекста: стереотипы советского кинематографического образ войнь и фильм В. Виноградова «Восточный коридор» (1966), «Вопросы культурологии» 2011, № 6, с. 110-116.

${ }^{17}$ А. Шпагин, Религия войны. Субъективные заметки о богоискательстве в кинематографе о войне, «Искусство кино» 2005, № 6.

${ }^{18}$ А. Красинский, Художественная кинолетопись героизма, «Коммунист Белоруссии» 1975 , № 7, с. 83. 
W okresie odwilży w studiu Belarusfilm zaczęto ekranizować dzieła białoruskiego pisarza Vasila Bykaŭa. Były frontowiec reprezentował tak zwaną prozę lejtenantów, w której bez upiększeń i przemilczeń autorzy ukazali widzianą oczyma szeregowego żołnierza prawdę okopów - było to świadectwo traumatycznej pamięci ${ }^{19}$. Opowiadania Bykaŭa o wojnie podnosiły egzystencjalne pytania o istotę człowieczeństwa, a bohaterowie utworów rozstrzygali te kwestie zgodnie z wartościami nie ideologicznymi, a ogólnoludzkimi, odrzucając tak zwaną moralność klasową ${ }^{20}$. Obca pisarzowi zideologizowana bohaterska narracja była atrakcyjna dla reżyserów okresu odwilży, których celem było otwarte mówienie o wojnie, bez sztampy ideologicznej. W 1963 r. miała miejsce premiera filmu Trzecia rakieta («Третья ракета», reż. Riczard Wiktorow), na podstawie opowiadania o tym samym tytule. Film odebrano przychylnie, chociaż autorów skrytykowano za ,przejawy remarkizmu” - rzekomo w większym stopniu interesowała ich „nie sama idea, w imię której walczą ludzie, a to, co w danej chwili przeżywają". Poza tym przypomniano, że reżyser ma obowiązek ukazywać bohaterów ,jako prawdziwych sowieckich ludzi". Wkrótce w kinach pojawiły się też inne ekranizacje utworów Bykaŭa - filmy Alpejska ballada («Альпийская баллада», 1965, reż. Boris Stiepanow), Pułapka («Западня», 1966, reż. Leonid Martyniuk) i in. Bykaŭ, podobnie jak inni przedstawiciele prozy lejtenantów, chcąc otwarcie opowiedzieć o doświadczeniu wojennym, musiał pokonać silny sprzeciw cenzury i krytyków oraz zachętę do „wyraźniejszego podkreślania patriotyzmu żołnierzy”"21. Jak wspominał autor, podczas tworzenia filmu zwykła scena żołnierskiej codzienności

${ }^{19}$ И. Кукулин, Регулирование боли (предварительные заметки о трансформации травматического опьтта Великой Отечественной / Второй мировой войны в русской литературе 1940-1970-х годов), «Неприкосновенный запас» 2005, № 2-3 [online], http://magazines.russ.ru/nz/2005/2/ku37-pr.html [dostęp: 13.03.2018].

${ }^{20}$ Беларусы. Т. 12. Экраннае мастацттва, рэд. А. Красінскі, Мінск 2009, с. 220 ; Л. Лазарев, Записки пожилого человека. Книга воспоминаний, Москва 2005 , c. $265-286$.

${ }^{21}$ Ukazują to opublikowane scenariusze filmowe V. Bykaŭa: В. Быкаў, Поўны збор творай у 14 m. Т. 9, Мінск 2012. 
w okopach stawała się „dysputą estetyczno-polityczną o tym, jak było, jak powinno być i co powie władza"22. Chociaż z biegiem czasu Bykaŭ stał się pisarzem, najczęściej ekranizowanym w studiu filmowym Belarusfilm $^{23}$, to jednak jego utwory przeniesione na taśmę filmową straciły charakterystyczne dla jego prozy egzystencjalne świadectwo okopowej prawdy, stając się opowieściami filmowymi o wojnie, ideologicznie bez zarzutu - albo, jak o ekranizacji jednego ze swoich dzieł powiedział sam twórca - filmem średnim, jednak ,,pod każdym względem poprawnym: heroicznym, patriotycznym"24. Najprawdopodobniej owo niezadowolenie autora wynikało z bardzo czujnej kontroli ideologicznej podczas przygotowywanej ekranizacji utworów i reżyserom trudno było przekroczyć nakreślone przez cenzurę ramy.

W okresie odwilży oficjalny schemat kanonicznej opowieści o wojnie w sposób najbardziej zdecydowany próbował przekroczyć reżyser Walentin Winogradow. Jego film z 1966 r. Wschodni Korytarz («Восточный коридор») śmiało przeciwstawiał się dominującej w kinie sowieckim narracji o wojnie. Bodajże po raz pierwszy w kinie sowieckim zawarto $\mathrm{w}$ nim odmienną od dotychczasowej interpretację wojny, którą ukazano jako „burzącą humanistyczny zalążek człowieka" i w sposób traumatyczny oddziałującą na obie walczące strony ${ }^{25}$. Wschodni Korytarz był głębokim dramatem psychologicznym, nasyconym symbolizmem i opowiadającym o tragizmie walczących. Tradycyjną bohaterską walkę sowieckich partyzantów zastąpiła opowieść o sowieckim podziemiu, które od wewnątrz niszczą wzajemne podejrzenia o zdradę. Sowieccy krytycy filmowi byli bezlitośni - film nazwano ,pretensjonalnym intelektualnym dramatem, utworem nasyconym estetycznym i etycznym cynizmem"26. Zirytował ich nie tylko

${ }^{22}$ В. Быкаў, Доугая дарога дадому, Мінск 2003, с. 151.

23 Экран и культурное наследие Беларуси, ред. А. Карпилова [и др.], Минск 2011, c. 208.

${ }^{24}$ В. Быкаў, Доўгая дарога..., с. 151.

${ }^{25}$ А. Федоров, op. cit., с. 110-116.

${ }^{26}$ А. Шпагин, op. cit. 
wybrany przez reżysera styl opowiadania, który nie miał nic wspólnego z realizmem socjalistycznym, ale też całkowite odejście od sowieckiej kanonicznej opowieści o wojnie, która miała jednoznacznie świadczyć o patriotyzmie ludu sowieckiego. Reżysera oskarżono o ukazanie w filmie wydarzeń nie mających nic wspólnego „,z prawdziwym życiem ludu i walką w okresie okupacji, a sam film narzucać miał widzom koncepcje obce dla rozumienia naszej historii”'27. Reżyser, ich zdaniem, dokonał zamachu na kanoniczną opowieść o bohaterskiej walce ludu, w której miejsce śmiałych, solidarnych, wierzących w swoje zwycięstwo bojowników zajęli zmęczeni bohaterowie. Film ten stanowił zamach na mit zwycięstwa, a ostra krytyka świadczyła o początku nowego okresu zastoju.

W październiku 1964 r. Chruszczowa zastąpił Leonid Breżniew, a odwilż zastąpił polityczny zastój. Zmiana na stanowisku lidera stała się też przełomem w polityce pamięci dotyczącej wojny, którą na nowo zaczęto aktualizować. W 1965 r. Dzień Zwycięstwa ponownie stał się dniem wolnym od pracy, wprowadzono tytuł miasta-bohatera (miastom, które najbardziej wyróżniły się w latach wojny nadawano to najwyższe sowieckie odznaczenie). Tylko w 1965 r. siedem miast ZSRR uzyskało tytuł miasta-bohatera, w tym tytuł twierdzy-bohatera nadano na Białorusi miastu Brześć. Władza podjęła decyzję o wydaniu nowej historii II wojny światowej w 12 tomach $^{28}$.

W latach siedemdziesiątych system sowiecki zaczął szeroko już eksploatować obrazy wojny i zwycięstwa nad faszyzmem zarówno w celu legitymacji swojego reżimu politycznego, jak i konstruowania tożsamości sowieckiego człowieka. Podczas jubileuszowych obchodów Dnia Zwycięstwa w 1975 r. lider partyjny wygraną wojnę nazwał „wielkim zwycięstwem ludu sowieckiego", które skonsolidowało sowieckie spo-

${ }^{27}$ И. Авдеев, Л. Зайцева, Все белорусские фильмы: каталог-справочник. Т. 1. Игровое кино (1926-1970), Минск 1996, с. 172.

${ }^{28}$ И. Хеслер, Что означает «проработка прошлого»? [в:] Память о войне 60 лет спустя. Россия, Германия, Европа, Москва 2005, с.159-160; Д. Андреев, Г. Бордюгов, op. cit., c. 20-25. 
łeczeństwo ${ }^{29}$. Mit zwycięstwa stał się jednym z podstawowych mitów sowieckich. Na Białorusi sowieckiej zrealizowano najważniejsze projekty, które stały się podstawowymi symbolami pamięci o wojnie: powstał wspomniany kompleks twierdza-bohater Brześć, postawiono pomnik żołnierzom sowieckim Kurhan Stawy oraz pomnik upamiętniający spaloną przez nazistów wieś Chatyń.

Przełom w polityce pamięci dotyczącej wojny wpłynął, rzecz jasna, również na opowieść filmową o tym wydarzeniu. Wymowną zmianę symbolizuje fragment powstałego w grudniu 1966 r. filmu Rodem $z$ dzieciństwa («Я родом из детства», reż. Viktar Turaŭ), w którym w 1945 r. lektor Jurij Lewitan informuje o ogłoszeniu 9 maja Dniem Zwycięstwa. Wykorzystany w filmie fragment archiwalnego nagrania niejako symbolicznie uprawomocniał odnowioną ,autentyczną" tradycję obchodów tego święta.

W latach zastoju doszło do przerwania podjętej w okresie odwilży próby bardziej otwartego mówienia w kinie o wojnie. Nastąpił niejako powrót do schematów i mitologemów kinematografii stalinowskiej, które odrodziły się, zyskując oficjalny status ${ }^{30}$. Wspomniany już ostro skrytykowany film Wschodni Korytarz wykorzystywany był przez „strażników” białoruskiej kinematografii jako przykład, w ich rozumieniu, „otwartego niepowodzenia czy błędnej decyzji” w tworzeniu filmu o wojnie $^{31}$. Znakiem koniunkturalnego zastoju politycznego stała się też krytyka pokazywanego na ekranach w 1968 r. lirycznego filmu Odpowiedni nie do stużby liniowej («Годен к нестроевой», 1968, reż. Władimir Rogowoj). Krytycy ubolewali, że delikatnie humorystyczna kreacja siedemnastoletniego bohatera może w oczach widza - jego rówieśnika, zdewaluować obraz heroicznej walki ${ }^{32}$.

Przerwaną próbę otwartego mówienia w okresie odwilży o wojnie w kinie sowieckim $\mathrm{w}$ pewnym stopniu kompensowało podejmowanie

\footnotetext{
${ }^{29}$ Ibidem, c. 30-31.

${ }^{30}$ А. Шпагин, op. cit.

${ }^{31}$ А. Красинский, op. cit., с. 84.

${ }^{32}$ И. Авдеев, Л. Зайцева, op. cit., с. 208-209.
} 
w filmach tematu traumatycznego doświadczenia wojennego. Pod koniec lat sześćdziesiątych ukazały się filmy, których twórcy podzielili się z widzem osobistym traumatycznym doświadczeniem związanym z walką partyzancką, walką na froncie lub życiem pod okupacją. Ojciec Turaŭa - reżysera filmu Rodem z dzieciństwa został rozstrzelany przez Niemców jako partyzant, a jego samego z matką i siostrami wywieziono do obozu koncentracyjnego. Traumatycznym doświadczeniem wojennym były też naznaczone biografie twórców (reżyserów, scenarzystów, operatorów) filmu Iwan Makarowicz («Иван Макарович», 1968, reż. Igor Dobrolubow). Tu przeżycia wojenne ukazano oczyma dzieci: codzienny niedostatek, ból utraty bliskich i, jako skutek, dojrzałość duchową wyprzedzającą dojrzałość fizyczną. W tym czasie zaczęto też mówić o doświadczeniu kobiet w czasie wojny - film reżysera Turaŭa Wojna pod dachami («Война под крышами», 1967), ороwiadający historię rodziny partyzanckiej, rozpoczyna się od wymownego epigrafu autora scenariusza filmu, pisarza Aliesia Adamoviča Wojna ma niekobieca twarz... Należy dodać, że Adamovič został partyzantem będąc nastolatkiem. Osobistym doświadczeniem zdobytym na froncie przesiąknięta była cała twórczość Bykaŭa, którą chętnie ekranizowali reżyserzy filmowi. Ideolodzy reżimu politycznego doskonale rozumieli zagrożenie, które dla systemu stwarzała otwarta, oparta na osobistym doświadczeniu, narracja, dlatego nie zachęcali do takiej opowieści o wojnie, jednak z drugiej strony rozumieli, że usankcjonowanie narracji o traumatycznym doświadczeniu stwarzało $\mathrm{w}$ widzach iluzję, iż o wojnie opowiadana jest cała ,prawda”.

W latach siedemdziesiątych pojawiło się też wiele filmów, demonstrujących przyjaźń między narodami bloku sowieckiego i wspólną walkę z faszyzmem. W taki sposób podkreślano internacjonalizm sowiecki, który rzekomo kształtował się i umacniał „w trakcie wspólnej walki z wrogiem". W białoruskim kinie również znalazła odzwierciedlenie ta tendencja. W 1972 r. na ekranach pojawił się film w reżyserii Aleksandra Karpowa Jutro będzie za późno... («3автра бydem поздно...»). Było to dzieło powstałe w koprodukcji z czechosłowackimi 
filmowcami, opowiadające historię bohatera Związku Radzieckiego, oficera słowackiego Jana Nalepki (1912-1943). W 1942 r. Nalepka służył w 101 pułku słowackim jako szef sztabu na okupowanej przez Niemców Białorusi. Wraz z grupą żołnierzy słowackich opuścił on pułk i dołączył do białoruskich partyzantów, później został przywódcą oddziału partyzanckiego złożonego z byłych żołnierzy pułku słowackiego. Film utrzymany na niezbyt wysokim poziomie artystycznym przychylnie odebrała zarówno władza Związku Radzieckiego, jak i Czechosłowacji, która twórców filmu nagrodziła nawet nagrodą państwową. Podobną przychylność władzy można wytłumaczyć ówczesnymi słowami oficjalnej krytyki, które głosiły, że wśród wielu filmów o tematyce wojennej jeszcze niewiele jest takich, w których wystarczająco wyraziście ukazano temat jedności internacjonalnej i braterstwa różnych narodów w walce z „największym wrogiem człowieczeństwa - faszyzmem”. Należy zauważyć, że w tym przypadku do promocji idei sowieckiego internacjonalizmu wybrano historię, która nie tylko doskonale nadawała się do ilustracji braterstwa broni między krajami bloku sowieckiego, ale też odpowiadała białoruskiej tradycji opowiadania o wojnie, która skupiała się na partyzantce.

Zainteresowanie białoruskiego kina historią wojny partyzanckiej zwiększało osobiste doświadczenie sowieckich elit politycznych Białorusi (znaczna część ich przedstawicieli podczas wojny należała do sowieckiej partyzantki). Pokolenie partyzantów w latach powojennych stało się klasą biurokratów, która w swoich rękach skupiła władzę ${ }^{33}$. Powstała nawet tak zwana frakcja partyzancka - powiązana nieformalnymi więzami wspólnota byłych sowieckich partyzantów, znajdujących się u władzy ${ }^{34}$. Na czele tej najbardziej wpływowej nieformalnej grupy stał lider sowieckiej Białorusi w latach 1965-1980, Piotr Mašeraŭ.

${ }^{33}$ П. Радлінг, Вялікая Айчынная вайна ў сьвядомасьичі беларусай, „Arche” 2008, № 5 , с. 43-64.

${ }^{34}$ М. Урбан, Беларуская савецкая эліта (1966-1986): алгебра ўлады, Vilnius 2010. 
W latach wojny był on jednym z przywódców partyzanckich na okupowanej przez Niemców Białorusi. Frakcja partyzancka była zainteresowana rozwijaniem narracji o ruchu podziemnym, gdyż zwiększało to jej kapitał symboliczny jako elity. Znane są przypadki, gdy przedstawiciele tej grupy zajmowali się lobbingiem. Mašeraŭ na przykład, wspierał pomysł reżysera Elema Klimowa stworzyć film o spalonej przez faszystów wsi Chatyń. Dzięki niemu na ekrany kin wszedł też film reżyser Larisy Szepitko Wznoszenie się («Восхождение»), na podstawie opowiadania Bykaŭa Sotnikaŭ ${ }^{35}$, stając się najlepszą ekranizacją dzieła tego pisarza w okresie sowieckim.

Próbując kontynuować rozpoczętą w okresie odwilży opowieść o codzienności wojny partyzanckiej, reżyser Turaŭ na podstawie powieści byłego partyzanta, pisarza Aliesia Adamoviča Partyzanci stworzył dylogię filmową Wojna pod dachami («Война под крышами») oraz Synowie ida do boju («Сыновья уходят в бой»), której premiera odbyła się 29 listopada 1971 r. w Moskwie. Opowieść w dwóch częściach o członkach białoruskiej rodziny, matce i jej synach, którzy zostali partyzantami, zapoczątkowała tradycję epickiej narracji o tej tematyce w kinie białoruskim. Jednak filmy te nie zadowoliły oczekiwań oficjalnej kinematografii. Reżyserska próba (w nawiązaniu do wcześniejszego filmu Przez cmentarz) pokazania niejednoznacznej codzienności wojny partyzanckiej i ujawnienia skomplikowanych, nawet sprzecznych charakterów bohaterów była dla krytyków nie do zaakceptowania. Żądali oni jasnego heroicznego przekazu, by widz, oceniając zachowanie tego lub innego bohatera, nie musiał się zastanawiać: „czy bohater to tchórz, dobry człowiek czy też niegodziwiec" - właśnie z takim zarzutem spotkał się autor dylogii ${ }^{36}$.

Cechą charakterystyczną sowieckiej kinematografii lat siedemdziesiątych było tworzenie epickich filmów na gruncie dokumentalnym.

${ }^{35}$ Więcej о tym: Э. Климов, Лариса: книга о Ларисе Шепитько, Москва 1987; Элем Климов. Неснятое кино, Москва 2008.

${ }^{36}$ И. Авдеев, Л. Зайцева, op. cit., с. 222-223. 
W centrum opowieści pozostawał nie czyn wykreowanej postaci, lecz masowe operacje wojenne lub zorganizowany opór podziemny/partyzancki i jego autentyczni przywódcy. Opowieści filmowe miały na celu ilustrację tezy powtarzanej w oficjalnej narracji o wojnie: jednomyślnej, ogólnoludowej (od marszałka do szeregowego) walki z nazizmem. Popularny w kinematografii sowieckiej gatunek epopei filmowej poświęconej wojnie, który najdobitniej reprezentują filmy reżysera Jurija Ozierowa: Wyzwolenie («Освобождение», 1968-1972), Żolnierze wolności («Солдаты свободы», 1977) і Bitwa o Moskwę («Битва за Москву», 1985) przeniknął również do kinematografii białoruskiej. Zyskał on swoisty odcień, bowiem filmy Ruiny strzelaja... («Руины стреляют...», 1970-1972, reż. Witalij Czetwierikow) oraz Czas wybrat nas («Время выбрало нас», 1976-1978, reż. Michail Ptašuk) opowiadały o partyzanckim i antynazistowskim ruchu oporu na okupowanej przez Niemców Białorusi ${ }^{37}$. Wzmacniały one obraz republiki partyzantów oraz podkreślały zasługi partii komunistycznej w organizowaniu oporu antynazistowskiego.

Jubileusz wyzwolenia Białorusi spod władzy nazistowskich Niemiec filmowcy uczcili, tworząc film Płomień («Пламя», 1974, reż. Witalij Czetwierikow) ${ }^{38}$. To opowieść o Uszacko-Lepelskiej operacji partyzanckiej, mającej miejsce wiosną 1944 r., w ramach której oddział liczący 17 tys. partyzantów walczył z niemiecką jednostką wojskową. Dokumentalna rekonstrukcja wydarzeń historycznych (od narady u Stalina poczynając, na szczegółowym odzwierciedleniu bitew kończąc) przeplatała się w filmie z symbolicznymi obrazami podkreślającymi myśl o szczególnym wkładzie partyzantów białoruskich w zwycięstwo w wojnie. Widz odnosił wrażenie, że właśnie dzięki partyzantom białoruskim pomyślnie przeprowadzono operację wojenną Bagration, wskutek której nie tylko doszło do wyzwolenia Białorusi, ale też wojsko niemieckie wypchnięto poza zachodnie granice Związku

\footnotetext{
${ }^{37}$ Беларусы..., с. 214-215.

${ }^{38}$ И. Новиков, Снимается «Пламя», «Правда» 1974, 28 апреля.
} 
Radzieckiego. Powstało dzieło, w którym wojna partyzancka na Białorusi, jak zauważyła gazeta «Правда», została ukazana z niespotykanym dotychczas rozmachem, nie zważając na to, że ów temat w białoruskiej kinematografii zawsze pozostawał jednym z najważniejszych ${ }^{39}$. Płomień bardzo dobrze ocenili białoruscy ideolodzy komunistyczni podkreślając, że twórcy opierali się na prawdziwych wydarzeniach historycznych, a film dawał „możliwość pełniejszego ukazania wiodącej roli Partii Komunistycznej w organizowaniu ogólnoludowego oporu"40. Wydaje się, że najważniejszą przyczyną, dla której elity Białorusi o partyzanckiej przeszłości tak pozytywnie oceniły Płomień był fakt, iż twórcy filmu podkreślili szczególną rolę partyzantów w latach wojny. Dla władzy forma epickiej opowieści filmowej o walkach sowieckich partyzantów umacniała obraz Białorusi jako republiki partyzanckiej, podkreślając jej wkład w walkę z faszyzmem. Uczestnicy wojny partyzanckiej, którzy wówczas znaleźli się u władzy, zyskali okazję, by poczuć się uczestnikami ważnych wydarzeń historycznych i wzmocnić swoją pozycję społeczną.

W 1975 r., w przeddzień Dnia Zwycięstwa, Aleksandr Karaganow (jeden $\mathrm{z}$ oficjalnych działaczy kinematografii), podkreślając $\mathrm{w}$ gazecie «Правда» wagę opowieści filmowej o wojnie i propagandy sowieckiego patriotyzmu, przypomniał twórcom kina, by uwydatniać „fakt”, iż zwycięstwo Związku Radzieckiego było uwarunkowane głębokim zakorzenieniem się idei komunistycznych w społeczeństwie, a najważniejsza prawda o wojnie jest taka, że zwyciężono pod kierownictwem partii komunistycznej ${ }^{41}$. Białoruska władza partyjna ze swojej strony zobowiązująco oświadczyła twórcom filmowym, że ,poprawne, dobre filmy o wojnie” powinny odznaczać się nie tylko „odpowiednimi informacjami poznawczymi o bohaterskim czasie", ale też w sposób ukierunkowany winny wychowywać widza, podkreślając, że „heroiczna prze-

${ }^{39}$ Н. Суменов, B тылу врага, «Правда» 1975, 21 октября.

${ }^{40}$ А. Красинский, op. cit., с. 81-82.

${ }^{41}$ А. Караганов, Война и люди, «Правда» 1975, 6 мая. 
szłość w sztuce - to nie jest zwykła dań oddana historii”, lecz niezbędny czynnik do wychowywania młodego pokolenia ${ }^{42}$.

Filmy o wojnie stały się ,tematem magistralnym” białoruskiej kinematografii - tak stwierdzono podczas okrągłego stołu zorganizowanego w 1978 r. w Mińsku przez sekretariat Związku Kinematograficznego Związku Radzieckiego. Jednocześnie oświadczono, że największe osiągnięcia białoruskiej kinematografii są związane $\mathrm{z}$ filmami o wojnie, bo reprezentują tak zwany bohatersko-patriotyczny temat. Wówczas zaczęto też mówić o obowiązku filmowców przypominania o wojnie młodemu pokoleniu, podkreślając, że podobne filmy ,nie są zwykłą pamięć o tragicznych wydarzeniach XX w.”, bowiem wojna wciąż pozostaje żywa w pamięci ludzi i można zaliczyć jej do kategorii tematów historycznych $^{43}$. Ten ostatni akcent (niechęć „oddania” wojny historii) nie był pustą retoryką propagandową. Świadczył o dążeniu do bardziej skutecznego wykorzystania mitu zwycięstwa do mobilizacji społeczeństwa, a wręcz pokonania kryzysu sowieckiej tożsamości, którą pogłębiał konflikt pokoleniowy. Mit zwycięstwa stał się apologią weteranów wojennych/frontowców, którzy znaleźli się u władzy, a młodzież musiała solidaryzować się z wartościami poprzedniego pokolenia i okazywać posłuszeństwo wobec jego autorytetu moralnego ${ }^{44}$.

Władza tworzyła i umacniała symboliczny kapitał weteranów wojennych, film zaś stał się ważnym narzędziem utrwalania ich pozytywnego wizerunku. W latach siedemdziesiątych w sowieckiej kinematografii nastąpiła kanonizacja obrazu weterana wojennego - stał się on niejako apostołem, którego misją było kreowanie sowieckiego świata według idealnego obrazu i sprawowanie roli sędziego sądu moralnego dla jego mieszkańców ${ }^{45}$. Służyły temu takie filmy radzieckie, jak: Dworzec Białoruski («Белорусский вокзал», 1970, reż. Andriej

\footnotetext{
${ }^{42}$ A. Красинский, op. cit., с. 85.

${ }^{43}$ В пути. Белорусское кино сегодня, «Искусство кино» 1978, № 6, с. 15-46.

${ }^{44}$ И. Кукулин, op . cit.

${ }^{45}$ А. Шпагин, op. cit.
} 
Smirnow), Adres waszego doти («Адрес вашего дома», 1972, reż. Jewgienij Chriniuk), Mieszczanie («Горожане», 1975, reż. Władimir Rogowoj). Podobną tendencję obserwowano w kinematografii białoruskiej: weteran wojny był ukazywany jako człowiek z zasadami, o nienagannej reputacji. Taka jest nieugięta i wymagająca sekretarz redakcji gazety obwodowej Anna Gubariewa w filmie Spotkanie pod koniec zimy («Встреча в конце зимы», 1978, reż. Iosif Szulman). Wierny swoim ideałom i towarzyszom bojowym pozostaje też były czołgista, który poszukuje przyjaciela wojennego w filmie Nieznana piosenka («Незнакомая песня», 1983, reż. Anatolij Kudriawcew). Przykładem do naśladowania dla młodego pokolenia obywateli sowieckich przez swój heroizm wykazany zarówno na wojnie, jak i w pokojowym życiu powojennym była również postać partyzantki w filmie Sprawdzian z zawodu («Контрольная по специальности», 1981, reż. Boris Szadurski). Filmy, jak Sprawdzian z zawodu, w których weterani w konfrontacji z młodym pokoleniem ukazani są jako przykład godny naśladowania, odpowiadał dyrektywnemu żądaniu reżimu sowieckiego „przybliżenia bohaterstwa przeszłości czasom współczesnym”46. Reprezentowane przez weteranów wartości miały być wskazówką dla młodego pokolenia obywateli sowieckich.

Dążenie władzy do wspierania i umacniania mitu zwycięstwa zachęcało do poszukiwania mechanizmu aktualizacji pamięci o wojnie. W latach siedemdziesiątych w kinematografii sowieckiej pamięć o wojnie zaczęto aktualizować poprzez współczesne świadectwa bohaterów wojennych. Wspomnienia żywych świadków wojny stały się narzędziem, zapewniającym zachowanie pamięci o wojnie, której nie da się i nie można zapomnieć. W filmach obok współczesnego protagonisty z traumatycznym doświadczeniem pojawił się antagonista z przeszłością nazistowską. Obraz Wezmę twój ból («Возьму твою боль», 1980, reż. Michail Ptašuk) opowiada historię o tym, jak do rodzinnej wsi po długim uwięzieniu wraca były pomocnik nazistów Szyszkowicz. Brał

${ }^{46}$ Д. Андреев, Г. Бордюгов, op. cit., s. 26. 
on udział w mordowaniu mieszkańców tej miejscowości. Zetknięcie się antagonisty $\mathrm{z}$ bohaterem, którego bliskich zamordował, nie tylko obnaża traumatyczne doświadczenia, ale też staje się dowodem na to (antagonista dokonuje zamachu na życie bohatera), że wobec przestępców wojennych nie obowiązuje termin przedawnienia. W filmie Świadek («Свидетель», 1985, reż. Walerij Rybariew) wspomnienia mieszkającego w domu dziecka Kolki Leteczki z nazistowskiego obozu koncentracyjnego dla dzieci ożywia proces sądowy nad pomocnikami nazistów. Kwintesencją owej tendencji w białoruskiej kinematografii może być fraza z filmu Ogród («Сад», 1983, reż. Witalij Czietwierikow): wojna skończy się dopiero wówczas, gdy kara spotka wszystkich nazistów i ich pomocników. Powstały w 1984 r. film Radunica («Радуница», 1984, reż. Jurij Maruchin), którego akcja rozgrywa się podczas tradycyjnego święta zmarłych, można oceniać dwojako: zarówno jako świadectwo filmowe tego, że traumatyczne doświadczenie wojenne dotknęło wszystkie rodziny białoruskie, jak i potwierdzenie sądu, iż obrazy wspomnień wojennych stały się organiczną częścią białoruskiej kultury pamięci.

W 1985 r. na ekranach kin w Związku Radzieckim pokazano powstałe w studiu filmowym Belarusfilm dzieło E. Klimowa Idź i patrz («Иди и смотри»), które stało się świadectwem zakończenia okresu zastoju politycznego i głosiło nowy kurs polityczny - pieriestrojkę. Ten film nie stanowił zamachu na sowiecki mit zwycięstwa, co więcej, akumulował wszystkie dotychczasowe wątki i obrazy narracji o wojnie. Są w nim obecne najwyraźniejsze symbole białoruskiej wojennej opowieści - to partyzantka i spalona przez faszystów wieś, którą symbolizowała Chatyń. Jednak ze względu na szokujące hiperrealistyczne wojenne obrazy, powstałe na motywach prozy A. Adamowiča oraz zwycięstwo po siedmioletniej walce reżysera $\mathrm{z}$ cenzurą ${ }^{47}$ film ten stał się symbolem nowej polityki głastnosti.

${ }^{47}$ М. Мурзина, «Иди и смотри»: съемки превратились для Элема Климова в борьбу с изензурой, «Аргументы и факты» 2010, 20 октября. 
Podsumowując, można stwierdzić, że powstałe w studiu filmowym Belarusfilm w latach 1946-1985 filmy fabularne o II wojnie światowej stały się odbiciem oficjalnej polityki historycznej reżimu sowieckiego. Ta polityka sprawiła, że bardziej otwarcie o wojnie zaczęto mówić w filmach powstałych w okresie odwilży, za panowania Chruszczowa (1953-1964), gdyż reżim polityczny dostrzegał korzyści w bardziej otwartym opowiadaniu o wojnie, które mogło przyczynić się do obalenia kultu Stalina. Film białoruski wyraźnie odzwierciedla zapoczątkowaną w ZSRR, poczynając od połowy lat sześćdziesiątych XX w. aktualizację pamięci o wojnie - obrazy zwycięstwa nad nazizmem szeroko wykorzystywano zarówno do legitymacji reżimu politycznego, jak i konstruowania tożsamości sowieckiego człowieka. Wówczas w studiu Belarusfilm powstało wiele filmów o tematyce wojennej, które swoją treścią odzwierciedlały podstawowe tendencje sowieckiej narracji o wojnie. Wyjątkową cechą białoruskiej opowieści o wojnie była szczególna uwaga poświęcana walkom białoruskich partyzantów.

\section{Bibliografia}

Авдеев И., Зайцева Л., Все белорусские фильмы: каталог-справочник. Т. 1. Игровое кино (1926-1970), Минск 1996.

Акудовіч В., Код адсутнасиі (асновы беларускай ментальнасиі), Мінск 2007. Андреев Д., Бордюгов Г., Пространство памяти: Великая Победа и власть, Москва 2005.

Беларусы. Т. 12. Экраннае мастаџтва, рэд. А. Красінскі, Мінск 2009.

Быкаў В., Поўны збор твораў у 14 m. Т. 9, Мінск 2012.

Быкаў В., Доўгая дарога дадому, Мінск 2003.

В пути. Белорусское кино сегодня, «Искусство кино» 1978, № 6.

Воронов А., Проблема правдоподобия и правды в советских и российских художественных фильмах, посвященных Великой Отечественной войне, «Вестник Ленинградского государственного университета им. А. С. Пушкина» 2010, № 2, с. 225.

Горных А., Медиа и общество, Vilnius 2013.

Земцов А., Фильм о патриотическом подвиге, «Правда» 1949, 12 сентября. Зоркая Н., История отечественного кино. ХХ век, Москва 2014. 
История отечественного кино, ред. Л. М. Будяк, Москва 2005.

Караганов А., Война и люди, «Правда» 1975, 6 мая.

Климов Э., Лариса: книга о Ларисе Шепитько, Москва 1987.

Копосов Н., Память строгого режима. История и политика в России, Москва 2011.

Красинский А., Художественная кинолетопись героизма, «Коммунист Белоруссии» 1975, № 7.

Кукулин И., Регулирование боли (предварительные заметки о трансформации травматического опьта Великой Отечественной / Второй мировой войны в русской литературе 1940-1970-х годов), «Неприкосновенный запас» 2005, № 2-3 [online], http://magazines.russ.ru/nz/2005/2/ku37-pr. html [dostęp: 13.03.2018].

Лазарев Л., Записки пожилого человека. Книга воспоминаний, Москва 2005.

Ливенцов В., Патриотический фильм, «Известия» 1949, 13 сентября.

Лінднэр Р., Гісторыкі і ўлада: наџылтвворчы праиэс і гістарычная палітыка $\check{y}$ Беларусі XIX-XX cm., Санкт-Петербург 2005.

Мурзина М., «Иди и смотри»: съемки превратились для Элема Климова в борьбу с иензурой, «Аргументы и факты» 2010, 20 октября.

Новиков И., Снимается «Пламя», «Правда» 1974, 28 апреля.

Орлова А., Способы воплощения «образа врага» в советском киноискусстве 1940-х годов (на материале художественных фульмов о Великой Отечественной войне), «Вестник Костромского государственного университета им. Н. А. Некрасова» 2015, № 4.

Радлінг П., Вялікая Айчынная вайна ў сьвядомасьиі беларусай, „Аrche” 2008, № 5.

Суменов Н., В тылу врага, «Правда» 1975, 21 октября.

Урбан М., Беларуская савецкая эліта (1966-1986): алгебра ўлады, Vilnius 2010.

Федоров А., Структурный анализ медиатекста: стереотипы советского кинематографического образ войны и фильм В. Виноградова «Восточный коридор» (1966), «Вопросы культурологии» 2011, № 6.

Хеслер И., Что означает «проработка прошлого»? [в:] Память о войне 60 лет спустя. Россия, Германия, Европа, Москва 2005.

Шпагин А., Религия войны. Субъективные заметки о богоискательстве в кинематографе о войне, «Искусство кино» 2005, № 6 .

Шыбека 3., Нарыс гісторыі Беларусі. 1795-2002, Мінск 2003.

Экран и культурное наследие Беларуси, ред. А. Карпилова [и др.], Минск 2011. Элем Климов. Неснятое кино, Москва 2008. 


\section{How Belarusian films in Soviet times narrated history of the World War II}

Image of the World War II was expressive in the Soviet Belarusian culture of remembrance, this was predetermined by not only the political regime historic policy, but also due to the fact that the war really left a deep footprint in the Belarusians' collective memory. In the Soviet Belarus film studio Belarusfilm («Беларусьфільм») was created about 70 artistic movies, which subject was history of the World War II. This paper analyzes how film studio Belarusfilm in 1946-1985 created films was told history of the World War II. It is tried to answer the question of how the feature films about the war reflected the official policy of Soviet regime history and develop Belarusian cinema narrative about the feature of the war. This article show that in film studio Belarusfilm 1946-1985 created artistic films about the World War II became official Soviet regime reflection of political history. Politic of political rezime history determined that about war was openly speak just in Khrushchev's thaw (1953-1964) time created films, because for political regime was useful openly narrative about war, which could serve to Stalin's identity cult destruction. Belarusian film reflect from the mid-sixties of the $20^{\text {th }}$ century an active memory of the war actualization in the Soviet Union started: began widely exploit images of the victory over Nazism both for its political regime legitimation and Soviet human identity construction. Belarusfilm studio increased number of the movies on the war theme which content reflected the main trends of Soviet narrative about the war. It is argued that exclusive belarusian film narrative feature about the war was special attention for Soviet Belarusians partisans fighting representation.

Keyw ord s: the World War II, policy of history, Belarus, cinema 